\title{
METODE COOPERATIVE LEARNING DALAM MENINGKATKAN KUALITAS HASIL BELAJAR DI MASA PANDEMI COVID-19
}

\author{
Vianita Prasetyawati \\ Fakultas Ilmu Pendidikan, Universitas Negeri Yogyakarta \\ e-mail: vianitaprasetyawati.2020@student.uny.ac.id
}

\begin{abstract}
Abstrak
Pandemi Covid-19 telah berpengaruh besar dalam bidang pendidikan, sebab demi menghentikan penyebaran virus Covid-19 semua siswa dan guru diwajibkan untuk melakukan kegiatan belajar mengajar (KBM) dari rumah. Sebagai penentu majunya pendidikan di suatu negara maka guru dituntut untuk lebih kreatif dan inovatif dalam memilih metode pembelajaran yang tepat agar kualitas hasil belajar siswa dapat ditingkatkan. Penelitian studi kepustakaan ini bertujuan untuk mengetahui kualitas hasil belajar siswa dengan menggunakan metode cooperative learning di masa pandemi Covid-19. Metode yang digunakan dalam penelitian ini adalah penelitian studi kepustakaan dengan pendekatan penelitian deskriptif kualitatif. Metode penelitian deskriptif kualitatif merupakan sebuah jenis penelitian yang memanfaatkan data kualitatif kemudian diuraikan secara deskriptif. Metode penelitian deskriptif kualitatif ini menggambarkan kondisi yang sebenarnya tanpa memberikan perlakuan atau memanipulasi variabel maupun data yang diteliti. Pada penelitian ini hasil analisis yang dilakukan oleh penulis yaitu setelah menerapkan metode cooperative learning di masa pandemi Covid-19 maka terjadi peningkatan kualitas hasil belajar yang optimal. Hal ini membuktikan bahwa metode cooperative learning berdampak positif terhadap pembelajaran siswa yaitu dapat dilihat dari tingkat partisipasi, interaksi, hasil kuis dan tes, serta hasil tugas kerja kelompok. Selain itu, secara umum siswa juga menyukai penerapan metode cooperative learning ini karena dianggap banyak memberikan manfaat. Kesimpulan dari penelitian ini yaitu metode cooperative learning merupakan metode pembelajaran yang memberikan kesempatan bagi siswa untuk berpikir kritis, menjawab pertanyaan, berbagi pendapat dan meningkatkan aktivitas siswa dalam belajar sehingga dapat meningkat kualitas hasil belajarnya.
\end{abstract}

Kata Kunci: pandemi covid-19, cooperative learning, kualitas hasil belajar

\section{COOPERATIVE LEARNING METHODS IN IMPROVING THE QUALITY LEARNING OUTCOMES DURING PANDEMIC COVID-19 PERIODE}

\begin{abstract}
The Covid-19 pandemic has had a major impact on the education sector, because in order to stop the spread of the Covid-19 virus, all students and teachers are required to carry out teaching and learning activities (KBM) from home. As a determinant of the progress of education in a country, teachers are required to be more creative and innovative in choosing the right learning methods so that the quality of student learning outcomes can be improved. This literature study research aims to determine the quality of student learning outcomes using the method cooperative learning during the Covid-19 pandemic. The method used in this research is a literature study research with a qualitative descriptive research approach. Qualitative descriptive research method is a type of research that utilizes qualitative data and then describes it descriptively. This qualitative descriptive research method describes the actual conditions without giving treatment or manipulating the variables or data being studied. In this study, the results of the analysis carried out by the author are that after applying the method cooperative learning during the Covid-19 pandemic, there was an increase in the quality of optimal learning outcomes. This proves that themethod cooperative learning has a positive impact on student learning, which can be seen from the level of participation, interaction, quiz and test results, and the results of group work assignments. In addition, in general students also like the application of this method cooperative learning because it is considered to provide many benefits. The conclusion of this research is that the cooperative learning method is a learning method that provides opportunities for students to think critically, answer questions, share opinions and increase student activity in learning so as to improve the quality of learning outcomes.
\end{abstract}

Keywords: pandemic covid-19, cooperative learning, quality of learning outcomes 


\section{PENDAHULUAN}

Pendidikan adalah salah satu elemen penting dalam pembangunan di suatu negara. Menurut Undang-Undang Sistem Pendidikan Nasional Nomor 20 Tahun 2003 dalam pasal 1 telah dijelaskan bahwa pendidikan merupakan usaha sadar dan terencana untuk mewujudkan suasana dan proses pembelajaran agar siswa secara aktif dapat mengembangkan dan meningkatkan potensinya untuk memiliki kekuatan spiritual, kepribadian, kecerdasan, akhlak mulia, serta keterampilan yang diperlukan oleh dirinya sendiri maupun masyarakat, bangsa dan negara. Tujuan dari pendidikan yaitu melahirkan manusia yang matang dan berwibawa secara lahir maupun batin yang berkaitan dengan keimanan, ketaqwaan, berilmu, kreatif, mandiri, cakap, dan bertanggung jawab. Dengan demikian, dapat ditarik kesimpulan bahwa pendidikan yaitu suatu sistem pembelajaran mengenai pengetahuan serta keterampilan yang diberikan untuk mengubah sikap atau tingkah laku manusia dalam usaha untuk mendewasakan melalui pengelolaan dan pelatihan. Peranannya sangat penting karena dengan pendidikan yang bermutu maka akan berpengaruh terhadap penciptaan Sumber Daya Manusia (SDM) yang berkualitas dan berdaya saing tinggi.

Lalu, bagaimana kondisi pendidikan di Indonesia ketika terjadi pandemi Covid-19 ? sejak mewabahnya virus Covid-19, hambatan Kegiatan Belajar Mengajar (KBM) menjadi persoalan dalam dunia pendidikan yang harus dihadapi oleh bangsa Indonesia. Kegiatan Belajar Mengajar (KBM) yang sebelumnya lebih banyak dilaksanakan di sekolah dengan bertatap muka secara langsung, kini harus dialihkan menjadi Pembelajaran Jarak Jauh (PJJ). Sistem pembelajaran jarak jauh ini tidak mengharuskan siswa datang ke sekolah untuk melaksanakan Kegiatan Belajar Mengajar (KBM). Hal ini dikarenakan dalam pelaksanaannya banyak guru yang memanfaatkan teknologi web dan internet seperti aplikasi Zoom, Google Meet, Google Classroom, Edmodo, Youtube, WhatsApp, dll untuk menciptakan proses belajar pada siswa. Dengan adanya hal tersebut maka diharapkan peran serta pemerintah dan instansi pendidikan dalam melaksanakan sistem pembelajaran yang sesuai dengan kebutuhan dan kemampuan siswa. Selain itu, pemilihan metode pembelajaran oleh guru juga sangat berpengaruh terhadap keberhasilan dan tingkat pemahaman siswa terhadap suatu pelajaran. Penerapan sistem dan metode pembelajaran yang tepat tentunya akan membantu mempermudah Kegiatan Belajar Mengajar $(\mathrm{KBM})$ serta berpotensi untuk meningkatkan kualitas hasil belajar siswa.

Namun, salah satu kelemahan dari penerapan Pembelajaran Jarak Jauh (PJJ) yaitu menjadikan siswa kurang aktif dalam menyampaikan aspirasinya sehingga Kegiatan Belajar Mengajar (KBM) terasa membosankan. Menurunnya perhatian dan keaktifan siswa dalam Kegiatan Belajar Mengajar (KBM) ini berpengaruh besar terhadap hasil belajarnya. Oleh karena itu, dengan situasi dan kondisi yang serba terbatas ini maka dibutuhkan kreativitas dan keterampilan guru dalam menciptakan suatu pembelajaran yang dapat menarik perhatian serta mendorong motivasi siswa untuk mengikuti Kegiatan Belajar Mengajar (KBM). Pendekatan pembelajaran yang akan dilakukan oleh guru harus disusun secara teratur dan terarah demi tercapainya suatu keberhasilan dari proses pembelajaran. Pembelajaran ini seharusnya berpijak pada konsep belajar yang telah dicanangkan oleh UNESCO yaitu mencakup learning to think, learning to do, learning to be dan learning to life together. Sedangkan, metode pembelajaran yang dibutuhkan adalah metode yang memungkinkan siswa untuk terbudayakannya suatu kecakapan dalam berpikir ilmiah, kreatif, inovatif, serta mampu memperoleh hasil belajar yang baik. Oleh sebab itu, dalam Kegiatan Belajar Mengajar (KBM) seharusnya siswa tidak hanya memperoleh pengetahuan, keterampilan, dan sikap saja. Salah satu metode pembelajaran yang mampu dan tepat untuk mengembangkan kualitas Sumber Daya Manusia (SDM) abad ke-21 adalah metode pembelajaran gotong royong atau yang sering disebut dengan metode cooperative learning (Mohammad Nur, 2000).

Cooperative learning merupakan metode pembelajaran yang memprioritaskan prinsip bekerja sama antarsiswa dengan kemampuan yang berbeda dalam suatu kelompok kecil untuk menyelesaikan tugas agar mencapai tujuan secara maksimal. Selain itu, metode ini juga memprioritaskan proses pencarian pengetahuan daripada transfer pengetahuan. Tujuan dari metode cooperative learning ini yaitu untuk meningkatkan kualitas hasil belajar akademik siswa, melatih sikap 
siswa dalam menerima keberagaman dari temannya, dan mengembangkan keterampilan sosial yang dimiliki oleh siswa. Pelaksanaan proses pembelajaran dengan metode ini tidak harus berasal dari guru tetapi siswa juga dapat saling mengajar, bertukar pikiran, dan berpendapat. Dalam metode ini siswa dipandang sebagai inti (subjek) dari proses pembelajaran yang perlu berpartisipasi secara aktif. Sedangkan, guru berperan sebagai fasilitator yang bertugas untuk membimbing dan mengkoordinasikan berlangsungnya Kegiatan Belajar Mengajar (KBM). Contoh penerapan Pembelajaran Jarak Jauh (PJJ) dengan metode cooperative learning ini yaitu guru membentuk siswa menjadi beberapa kelompok kecil dan memberikan masingmasing kelompok tersebut tugas, kemudian hasilnya dipresentasikan melalui aplikasi meeting online. Selanjutnya, hasil tersebut didalami dan ditanggapi oleh kelompok lain sehingga akan terjadi proses pembelajaran yang dinamis. Pada tahap ini, siswa diarahkan untuk mandiri dalam mencari atau menemukan berbagai informasi faktual serta membangun konsep dan nilai-nilai baru yang diperlukan untuk kehidupannya mendatang. Oleh karena itu, diharapkan metode cooperative learning ini mampu menjadi salah satu pemecahan dari permasalahan pendidikan yaitu kualitas hasil belajar siswa di masa pandemi Covid-19.

Artikel ini bertujuan untuk mengetahui apakah dengan menerapkan metode cooperative learning dalam Kegiatan Belajar Mengajar (KBM) ini mampu untuk meningkatkan kualitas hasil belajar siswa di masa pandemi Covid-19. Hasil dari penelitian ini nantinya dapat digunakan sebagai bahan pertimbangan atau referensi bagi guru untuk mengambil kebijakan dan keputusan dalam rangka meningkatkan kualitas hasil belajar siswa. Apabila metode ini berhasil direalisasikan dan dikembangkan maka upaya penerapan paradigma baru dalam pendidikan berbasis kompetensi dapat segera diwujudkan. Dengan demikian, artikel ini akan membahas tentang keterkaitan metode cooperative learning dengan kualitas hasil belajar siswa, penerapan metode cooperative learning dalam Kegiatan Belajar Mengajar (KBM) di masa pandemi Covid-19, upaya yang dapat dilakukan oleh guru dan teknolog pendidikan agar penerapan metode cooperative learning berjalan dengan efektif dan efisien, serta kelebihan dan kekurangan dari penerapan metode cooperative learning dalam Kegiatan Belajar Mengajar (KBM).

\section{METODE}

Metode yang digunakan pada penelitian ini yaitu deskriptif kualitatif. Metode penelitian deskriptif kualitatif adalah salah satu jenis analisis yang cenderung menjelaskan suatu fenomena atau data yang didapatkan. Fenomena atau data tersebut didapatkan dari jurnal maupun artikel dengan teknik pengumpulan yaitu editing, finding, dan organizing. Setelah data terkumpul dan diolah selanjutnya diadakan proses editing atau diperiksa kembali dari segi kelengkapan, kejelasan, dan kesamaan arti antara satu dengan yang lain. Selanjutnya yaitu proses organizing, dengan cara mengorganisasi atau menyusun data-data tersebut sehingga hanya terdapat data yang sesuai. Terakhir proses finding yaitu menganalisis data dengan menggunakan teoriteori yang relevan untuk ditarik suatu kesimpulan. Adapun syarat yang digunakan untuk memilah beberapa sumber bacaan yang telah ditemukan yaitu jurnal maupun artikel harus menjelaskan pembelajaran di masa pandemi Covid-19, jurnal maupun artikel tersebut harus berhubungan dengan metode cooperative learning dan hasil belajar siswa, serta penggunaan bahasa dalam jurnal maupun artikel harus baku dan mudah dipahami.

\section{HASIL DAN PEMBAHASAN Hasil}

Cooperative learning adalah suatu metode pembelajaran yang memerlukan kontribusi dan kerja sama antara anggota kelompok. Hal tersebut diperlukan agar dapat meningkatkan kinerja belajar antarsiswa pada saat mengikuti Kegiatan Belajar Mengajar (KBM) serta mampu menumbuhkan sikap tolong-menolong dalam berperilaku sosial. Cooperative learning sebagai metode pembelajaran yang melibatkan kerja sama dalam suatu kelompok kecil yang terdiri dari siswa dengan kemampuan berbeda-beda untuk menyelesaikan tugas-tugas akademiknya (Slavin, 2011: 4). Cooperative learning lebih dari sekadar kerja sama secara berkelompok karena tugas yang diberikan dalam metode pembelajaran ini bersifat kooperatif sehingga memungkinkan terjadinya interaksi serta terbentuknya hubungan interdependensi di antara anggota dalam kelompok. 
Metode cooperative learning yaitu metode pembelajaran yang menuntut siswa dengan tingkat kemampuan yang berbeda untuk belajar dalam suatu kelompok kecil. Oleh sebab itu, dalam menyelesaikan tugas kelompok dibutuhkan kerja sama secara kolaboratif dan saling membantu satu sama lain untuk memahami materi pembelajaran, memeriksa dan mengoreksi jawaban, serta kegiatan lainnya dengan tujuan untuk mencapai hasil belajar yang maksimal. Kegiatan belajar dengan metode cooperative learning belum dianggap sempurna apabila salah satu dari anggota kelompok belum memahami dan menguasai materi pembelajaran yang telah diberikan. Metode cooperative learning dapat diartikan sebagai struktur tugas bersama diantara sesama anggota kelompok. Selain itu, metode cooperative learning juga sering diartikan sebagai konsep kerja sama di mana setiap individu diarahkan pada preposisi dan pilihan yang harus dijalani yaitu apakah harus memilih bekerja sama, berkompetisi, atau justru individual. Penerapan metode cooperative learning dalam pembelajaran membutuhkan partisipasi dan kerja sama antara anggota kelompok.

Tujuan dari metode cooperative learning sangat berbeda dengan tujuan dari kelompok metode tradisional lainnya yang menerapkan sistem kompetisi, di mana keberhasilan individu diorientasikan pada kegagalan orang lain. Tujuan dari metode cooperative learning ini yaitu menciptakan kondisi di mana keberhasilan individu ditentukan oleh keberhasilan dari kelompoknya sendiri. Terdapat tiga tujuan dari metode cooperative learning, yaitu: (1) Hasil Belajar Akademik. Dalam metode cooperative learning tidak hanya meliputi beragam tujuan sosial, namun juga meliputi langkah untuk memperbaiki prestasi siswa atau tugas-tugas akademik penting lainnya. Metode cooperative learning juga bermanfaat untuk siswa yang memiliki prestasi rendah, sedang maupun tinggi karena mereka dapat saling bekerja sama dalam memecahkan persoalan dengan teman sebayanya; (2) Penerimaan Perbedaan. Tujuan lain dari metode cooperative learning adalah penerimaan secara luas dari orang-orang yang berbeda baik berdasarkan ras, suku, budaya, kelas sosial, kemampuan dan ketidakmampuannya untuk bekerja sama dalam memecahkan persoalan akademik. Melalui struktur penghargaan ini maka siswa dapat saling menghargai satu dengan yang lainnya; dan (3) Pengembangan Keterampilan Sosial. Tujuan yang ketiga dari metode cooperative learning ini yaitu mengajarkan siswa mengenai keterampilan untuk bekerja sama dan berkolaborasi. Keterampilan sosial ini sangat perlu dimiliki oleh setiap siswa, sebab saat ini banyak generasi muda yang keterampilan sosialnya masih kurang. Dengan penerapan metode cooperative learning ini maka diharapkan para siswa dapat menerima perbedaan satu sama lain, saling menghargai dan menghormati pendapat orang lain, saling mengoreksi kesalahan secara bersamasama, dan lain sebagainya. Selain itu, siswa juga dapat mencari sumber referensi (seperti buku paket, buku LKS, buku-buku yang ada di perpustakaan, dll) untuk dijadikan sebagai bahan dalam mencari jawaban dan untuk memperoleh pemahaman terhadap materi pelajaran yang telah disediakan di dalam silabus.

Metode cooperative learning merupakan rangkaian proses pembelajaran yang dilakukan oleh siswa dalam kelompok tertentu untuk mencapai tujuan yang telah ditetapkan. Unsurunsur penting dalam metode cooperative learning, diantaranya yaitu: (1) Adanya peserta dalam kelompok. Peserta tersebut adalah siswa yang akan melakukan proses pembelajaran secara berkelompok. Dalam pengelompokkan siswa ini biasanya ditetapkan berdasarkan beberapa pendekatan, seperti pengelompokkan berdasarkan atas minat, bakat, maupun kemampuan siswa. (2) Adanya aturan dalam kelompok. Aturan kelompok ini merupakan suatu kesepakatan dari semua pihak yang telah terlibat. Misalnya aturan tentang pembagian tugas, waktu pelaksanaan, tempat yang akan digunakan, dan lain sebagainya; (3) Adanya upaya belajar dari setiap anggota kelompok. Upaya belajar ini merupakan segala bentuk aktivitas siswa untuk meningkatkan kemampuan yang telah dimilikinya maupun meningkatkan kemampuan baru, baik dalam aspek pengetahuan, keterampilan, maupun sikap. Antara siswa dalam kelompok dapat saling membelajarkan melalui tukar pikiran, pengalaman, ide, maupun gagasan; dan (4) Adanya tujuan yang harus dicapai. Tujuan ini dimaksudkan untuk memberikan arah perencanaan, pelaksanaan serta evaluasi. Metode cooperative learning memiliki dua komponen utama, yang terdiri dari: a) komponen tugas kooperatif (cooperative task) yaitu berhubungan dengan semua hal yang dapat menyebabkan kerja sama antara angggota untuk menyelesaikan tugas kelompok; b) komponen struktur insentif kooperatif (cooperative incentive structure) yaitu semua hal yang dapat membangkitkan motivasi anggota kelompok untuk bekerja sama dalam mencapai tujuan. 
Karakteristik dari metode cooperative learning antara lain: (1) Pembelajaran dilaksanakan secara berkelompok. Metode cooperative learning merupakan pembelajaran secara berkelompok untuk mencapai tujuan tertentu. Oleh karena itu, setiap kelompok harus mampu membuat anggotanya saling belajar dan saling membantu demi mencapai tujuan yang diharapkan. Dalam metode cooperative learning setiap kelompok bersifat heterogen yang berarti bahwa di dalam kelompok terdapat anggota yang memiliki jenis kelamin, kemampuan akademik, dan latar belakang yang berbeda-beda. Hal tersebut ditujukan kepada setiap anggota kelompok agar saling membagikan pengalaman serta saling memberi dan menerima masukan sehingga diharapkan setiap anggota kelompok tersebut dapat turut andil dalam memberikan kontribusinya terhadap keberhasilan kelompok. (2) Didasarkan pada manajemen kooperatif. Manajemen dalam metode cooperative learning mempunyai empat fungsi pokok, yaitu: a) fungsi perencanaan, fungsi ini menunjukkan bahwa metode cooperative learning memerlukan perencanaan yang matang agar proses pembelajaran dapat berjalan dengan efektif dan efisien, misalnya tujuan apa yang hendak dicapai, bagaimana cara mencapai tujuan tersebut, apa yang perlu dipersiapkan untuk mencapai tujuan tersebut, dan lain sebagainya; b) fungsi pelaksanaan, fungsi ini menunjukan bahwa metode cooperative learning harus dilaksanakan sesuai dengan perencanaan yang sudah disiapkan dan melalui langkah-langkah pembelajaran yang telah ditentukan termasuk pula ketentuanketentuan yang sudah disepakati bersama; c) fungsi organisasi, fungsi ini menunjukkan bahwa metode cooperative learning merupakan kegiatan belajar bersama antara anggota kelompok. Oleh sebab itu, tugas dan tanggung jawab dari setiap anggota kelompok perlu diatur dengan baik; d) fungsi kontrol, fungsi ini menunjukkan bahwa dalam metode cooperative learning perlu menentukan kriteria keberhasilannya melalui tes maupun non tes. (3) Kemampuan untuk bekerja sama. Prinsip bekerja sama perlu ditekankan dan diterapkan dalam metode cooperative learning karena keberhasilan metode ini ditentukan oleh keberhasilan kerja sama dalam kelompok. Dengan demikian, tugas dan tanggung jawab dari masingmasing anggota kelompok bukan saja harus diatur tetapi juga perlu ditanamkan sikap saling membantu satu sama lain, misalnya siswa yang pintar perlu membantu siswa lain yang kurang pintar. (4) Keterampilan bekerja sama.
Kemampuan untuk bekerja sama diterapkan melalui aktivitas diskusi antarsiswa yang terlihat dalam keterampilan bekerja sama. Dengan demikian, siswa perlu didorong untuk bersedia dan mampu untuk berinteraksi dengan anggota kelompok yang lainnya. Siswa perlu dibantu dan dibimbing untuk mengatasi berbagai persoalan dalam berinteraksi sehingga mereka memiliki kesempatan yang sama dalam menyampaikan gagasan dan memberikan kontribusi kepada keberhasilan kelompoknya masing-masing (Sanjaya, 2012: 244-246).

Terdapat 6 fase dalam metode cooperative learning yang bisa dilakukan oleh guru, fase tersebut yaitu: (a) Fase 1: fase dimana guru menyampaikan kepada siswa tentang tujuan pembelajaran yang ingin dicapai pada pelajaran tersebut dan memotivasi siswa agar bersemangat dalam belajar; (b) Fase 2: fase dimana guru menyajikan materi kepada siswa disertai dengan peragaan (demonstrasi) maupun teks; (c) Fase 3: fase dimana guru mengorganisasikan siswa ke dalam kelompok belajar. Selain itu, guru juga membantu setiap kelompok agar melakukan perubahan yang efektif dan efisien; (d) Fase 4: fase dimana guru membimbing setiap siswa pada saat mereka mengerjakan tugas secara berkelompok; (e) Fase 5: fase dimana guru mengevaluasi hasil belajar siswa tentang materi yang telah dipelajari atau masing-masing kelompok secara bergantian mempresentasikan hasil kerja sama mereka; dan (f) Fase 6: fase dimana guru memberikan feedback atau hadiah untuk menghargai siswa, baik dalam usaha menyelesaikan tugas dengan baik maupun hasil belajar individu dan kelompok (Muslich, 2007: 230).

\section{Pembahasan}

Pandemi Covid-19 merupakan suatu peristiwa yang baru khususnya di dunia pendidikan. Hal tersebut mengharuskan guru dan siswa untuk menguasai teknologi sesuai dengan program yang telah dicanangkan oleh pemerintah. Kegiatan Belajar Mengajar (KBM) yang sebelumnya dapat dilaksanakan secara tatap muka secara langsung, kini harus beralih menjadi Pembelajaran Jarak Jauh (PJJ) yaitu dengan memanfaatkan jaringan internet. Seiring berjalannya waktu, perhatian siswa pada saat mengikuti pembelajaran secara online lambat-laun semakin menurun. Fenomena ini harus segera diatasi dengan adanya dorongan yang dapat membangkitkan siswa agar mereka memiliki semangat belajar yang tinggi. Oleh karenanya, dengan kondisi yang serba terbatas 
ini maka dibutuhkan pemahaman, keterampilan, kecakapan, dan kreativitas guru dalam menciptakan pembelajaran online supaya lebih menarik dan mampu meningkatkan motivasi siswa dalam mengikuti Kegiatan Belajar Mengajar (KBM). Salah satu metode pembelajaran yang mumpuni dan dapat diterapkan oleh guru di saat pandemi Covid-19 ini yaitu metode cooperative learning.

Cooperative learning adalah salah satu metode pembelajaran secara berkelompok yang memliki aturan-aturan tertentu. Prinsip dari metode cooperative learning yaitu siswa dibentuk menjadi beberapa kelompok kecil dan saling menbelajarkan satu sama lain untuk mencapai tujuan bersama. Dalam pembelajaran dengan metode cooperative learning ini siswa yang memiliki kemampuan kurang dalam memahami materi dapat belajar dengan suasana yang menyenangkan karena banyak dari temannya yang bisa membantu dan memotivasinya untuk belajar. Siswa yang sebelumnya sering pasif dalam pembelajaran, setelah menggunakan metode cooperative learning maka ia akan menjadi turut serta dalam berpartisipasi secara aktif supaya diterima oleh anggota kelompoknya. Tujuan dari metode cooperative learning ini yaitu menciptakan situasi dan kondisi belajar yang menyenangkan di mana keberhasilan individu ditentukan oleh keberhasilan dari kelompoknya sendiri.

Berdasarkan teori yang telah diuraikan sebelumnya bahwa metode cooperative learning sebagai suatu proses pembelajaran yang terdiri dari beberapa kelompok kecil sehingga siswa dapat bekerja sama untuk memaksimalkan pemahaman dan pengetahuannya dan dapat saling belajar satu dengan yang lain. Pada penerapan metode cooperative learning ini siswa dibagi secara heterogen supaya siswa dapat saling bekerja sama untuk mencapai tujuan pembelajaran sehingga akan tercipta kolaborasi antarsiswa. Masing-masing kelompok kecil yang telah dibentuk kemudian berdiskusi untuk menentukan topik dan saling belajar untuk bertanggung jawab terhadap pembelajaran yang dilaksanakan. Hasil diskusi mereka kemudian dipresentasikan kepada kelompok lain untuk dipelajari dan ditanggapi sehingga akan terjadi proses pembelajaran yang dinamis. Metode cooperative learning ini dapat membantu siswa agar lebih mudah untuk memproses informasi yang diperolehnya.
Penerapan metode cooperative learning di saat pandemi Covid-19 ini membutuhkan semangat dalam bekerja sama yang menekankan pada kegiatan belajar siswa secara berkelompok. Interdependece positive merupakan tujuan utama dari metode cooperative learning. Selain itu, metode cooperative learning juga berpijak pada kegiatan belajar yang dilakukan oleh kelompok siswa dalam kondisi yang memenuhi kriteria: (1) saling bergantung dalam hal yang positif dan sifatnya membangun, (2) akuntabilitas individu, (3) kontribusi dan interaksi, (4) pemanfaatan keterampilan interpersonal, dan (5) penilaian diri dalam fungsi kelompok. Dengan demikian, penelitian yang ekstensif ini akan menunjukkan bahwa penerapan metode cooperative learning berorientasi pada hasil belajar siswa yang lebih baik serta dapat mengembangkan keterampilan berkomunikasi dan bekerja sama dalam kelompok (misalnya kepemimpinan, manajemen proyek, keterampilan pemecahan masalah, dan lain sebagainya).

\section{Keterkaitan Metode Cooperative Learning dengan Kualitas Hasil Belajar Siswa}

Cooperative learning adalah metode pembelajaran yang terdiri dari beberapa kelompok kecil dengan setiap kelompok berjumlah empat sampai enam siswa yang heterongen. Siswa secara aktif akan belajar di dalam kelompoknya masingmasing untuk menyelesaikan tugas individual maupun kelompok. Hasil diskusi dari kelompok tersebut kemudian dipresentasikan kepada kelompok lain untuk dipelajari dan ditanggapi. Dalam memahami materi pelajaran yang telah diberikan oleh guru maka setiap anggota kelompok harus saling membantu dengan cara membelajarkan satu sama lain karena hal ini akan sangat berpengaruh terhadap kemampuan penguasaan materi. Selain itu, hal tersebut juga akan berpengaruh terhadap peningkatan kualitas hasil belajar siswa. Hasil belajar siswa merupakan dampak dari aktivitas yang dapat dilihat perubahannya melalui pengetahuan, pemahaman, kecakapan, keterampilan, dan nilai sikap melalui ujian tulis maupun ujian lainnya. Hasil belajar terbagi menjadi tiga ranah yaitu ranah kognitif, afektif, dan psikomotorik. Hasil belajar akan tercapai apabila telah memenuhi indikator berikut: (1) daya serap siswa terhadap bahan pelajaran yang diajaran mencapai nilai yang maksimal (2) perilaku yang diharapkan dalam tujuan pembelajaran atau instruksional khusus telah dicapai oleh siswa baik secara individu atau kelompok (Susanto, 2013). 
Metode cooperative learning berbeda dengan metode pembelajaran yang lainnya. Perbedaan tersebut dapat dilihat dari proses kerja sama antara anggota di dalam kelompok. Adanya kerja sama inilah yang menjadi ciri khas atau kekhasan dari metode cooperative learning. Belajar melalui metode cooperative learning dapat dijelaskan dari beberapa perspektif, diantaranya yaitu: (a) Perspektif sosial yaitu melalui metode cooperative learning ini setiap siswa akan saling membantu karena mereka ingin semua anggota kelompok memperoleh keberhasilan dalam belajar; (b) Perspektif motivasi yaitu sebuah penghargaan yang diberikan kepada kelompok sehingga akan memungkinkan setiap anggota kelompok saling membantu. Dengan demikian, dapat dikatakan bahwa keberhasilan individu pada dasarnya merupakan keberhasilan kelompok juga. Hal seperti inilah yang tentunya akan mendorong setiap anggota kelompok untuk memperjuangkan dan mempertahankan keberhasilan kelompoknya; dan (c) Perspektif perkembangan kognitif yaitu dengan adanya interaksi antara anggota kelompok maka akan lebih mudah untuk mengembangkan prestasi siswa dalam berpikir dan mengolah berbagai informasi yang didapatnya. Elaborasi kognitif ini berarti bahwa setiap siswa akan selalu berusaha untuk memahami dan mencari informasi yang sesuai dalam rangka memperbanyak pengetahuan kognitifnya.

Robert Slavin mengungkapkan bahwa metode cooperative learning merupakan salah satu bentuk dari paham pembelajaran konstruktivisme yang berarti bahwa teknik pembelajaran dengan metode ini melibatkan siswa untuk membina pengetahuannya sendiri secara aktif dengan menggunakan pengetahuan yang telah dimiliki sebelumnya. Dengan adanya komunikasi antarsiswa di dalam pelaksanaan metode cooperative learning ini maka dapat membuat siswa tersebut cepat memahami dan menganalisis suatu materi yang sedang dibahas. Dengan penjelasan dari temannya yang lebih pandai maka akan mempermudah siswa yang memiliki keterlambatan dalam menyerap ilmu untuk memahami materi yang sedang didiskusikan. Selain itu, para siswa juga dilatih untuk belajar mendengarkan dan menghargai pendapat orang lain. Penerapan metode ini menjadi sarana bagi siswa yang pandai untuk menanamkan karakter seperti tenggang rasa, peduli, bertanggung jawab, dan melatih kemampuan mereka dalam berkomunikasi. Melalui proses pembelajaran ini secara tidak langsung para siswa yang pandai akan mudah memperdalam dan memperluas pengetahuannya sehingga mereka akan belajar lebih giat supaya bisa lebih baik dalam menjelaskan materi kepada teman sekelompoknya. Oleh karena itu, hal ini jelas dapat membantu siswa dalam meningkatkan kualitas hasil belajarnya. Dengan demikian, dapat ditarik kesimpulan bahwa metode cooperative learning memiliki keterkaitan dalam upaya peningkatan kualitas hasil belajar siswa.

\section{Penerapan Metode Cooperative Learning dalam Kegiatan Belajar Mengajar (KBM) di Masa Pandemi Covid-19}

Cooperative learning merupakan metode pembelajaran yang mudah diterapkan. Selain itu, metode ini juga sangat berperan dalam membentuk karakter siswa, baik karakter bermoral, berkinerja, berelasi, maupun spiritual. Langkah pertama yang dapat dilakukan guru dalam penerapan metode pembelajaran ini yaitu memilih beberapa siswa yang terlihat lebih pandai dari teman-temannya untuk diberikan penjelasan terlebih dahulu mengenai hal apa saja yang harus dilakukan dalam kelompoknya. Kemudian, siswa dibagi menjadi beberapa kelompok kecil yang anggotanya terdiri dari siswa pandai dan siswa yang kurang pandai agar terjalin hubungan interaksi antarsiswa. Keaktifan dari anggota kelompok sangat dibutuhkan untuk mencapai keberhasilan dalam mendiskusikan materi yang ditugaskan oleh guru. Dalam penerapan metode cooperative learning ini tugas guru adalah mengontrol, membimbing, dan memfasilitasi siswa pada saat pelaksanaan diskusi berlangsung. Guru dapat memanfaatkan teknologi web dan internet seperti aplikasi Google Meet, Zoom, Google Classroom, Youtube, WhatsApp, dan platform lainnya untuk menunjang pembelajaran. Hasil belajar siswa yang mempraktikkan metode ini dinilai lebih baik daripada dengan metode pembelajaran konvensional. Di samping itu, komunikasi dan sikap toleransi antarsiswa menjadi lebih baik sebab mereka saling menghargai perbedaan latar belakang, suku, ras, agama, budaya, dan lain sebagainya.

Namun, dalam penerapan metode cooperative learning ini tidak selalu berjalan sesuai dengan apa yang diharapkan meskipun telah dirancang sedemikian rupa, terutama dengan adanya keterbatasan di masa pandemi Covid-19 ini. Hal-hal yang dapat menghambat Kegiatan 
Belajar Mengajar (KBM) terutama dalam implementasi metode cooperative learning diantaranya yaitu sebagai berikut: (1) Kurangnya pemahaman guru tentang penerapan metode cooperative learning dalam pembelajaran. (2) Banyaknya jumlah siswa sehingga berdampak pada minimnya perhatian guru terhadap proses pembelajaran dan terkadang hanya terdapat beberapa siswa saja yang menguasai materi. (3) Kurangnya sosialisasi dari pihak terkait mengenai penerapan metode cooperative learning yang baik dan sesuai standar. (4) Terbatasnya ketersediaan sumber bacaan sebagai media pembelajaran. dan (5) Terbatasnya pengetahuan siswa terhadap teknologi dan informasi yang dapat digunakan untuk mendukung proses pembelajaran. Oleh sebab itu, untuk mengatasi hal tersebut diperlukan adanya koordinasi yang lebih intensif antara pihak sekolah, dinas pendidikan, orang tua dan masyarakat agar hambatan tersebut dapat teratasi dengan baik. Kebijakan dari pemerintah juga sangat dibutuhkan sekaligus sebagai bagian dari partisipasi masyarakat dalam mensosialisasikan situasi dan kondisi di saat pandemi serta pencegahannya dari penularan virus Covid-19 tersebut. Metode cooperative learning ini dapat diterapkan di semua jenjang pendidikan, baik SD, SMP, SMA/SMK, maupun perguruan tinggi negeri/swasta. Penerapan metode cooperative learning di setiap jenjang pendidikan ini juga memerlukan strategi pembelajaran yang sesuai. Misalnya di $\mathrm{SD} /$ sederajat memerlukan perhatian lebih karena tahap awal yang dilakukan yaitu melatih siswa untuk berkomunikasi dan bersosialisasi dengan teman sebayanya. Sementara itu, di SMP/sederajat dan SMA/sederajat metode pembelajaram ini sangat sesuai dalam hal melatih siswa agar berani mengemukakan pendapatnya dan berani tampil saat mempresentasikan hasil diskusi kelompok. Sedangkan, di perguruan tinggi negeri/swasta tentunya metode pembelajaran ini sangat bagus untuk melatih kemampuan mahasiswa dalam bernegosiasi atau berunding dan kemampuan lainnya yang sangat dibutuhkan ketika mereka terjun langsung di masyarakat / di lingkungan kerjanya.

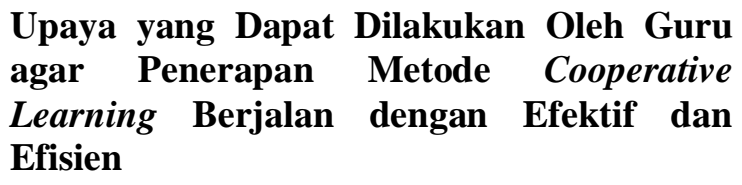

Agar penerapan metode cooperative learning ini dapat berjalan dengan efektif dan efisien, maka upaya yang dapat dilakukan oleh guru yaitu sebagai berikut:

1. Sebaiknya guru mempelajari terlebih dahulu mengenai teknik-teknik yang tepat dalam menerapkan metode cooperative learning sehingga materi yang akan diajarkan dapat sesuai dengan yang diharapkan.

2. Pembagian siswa ke dalam kelompok harus merata atau heterogen.

3. Diadakannya sosialisasi dari pihak terkait mengenai metode cooperative learning beserta penerapannya.

4. Meningkatkan ketersediaan sarana dan prasarana yang memadai guna mendukung berlangsungnya suatu Kegiatan Belajar Mengajar (KBM) terutama sumber bacaan.

5. Melakukan sosialisasi kepada siswa beserta wali muridnya mengenai pentingnya teknologi dan informasi yang dapat menunjang Kegiatan Belajar Mengajar $(\mathrm{KBM})$.

Upaya yang Dapat Dilakukan Oleh Teknolog Pendidikan agar Penerapan Metode Cooperative Learning Berjalan dengan Efektif dan Efisien

Selain guru, Teknolog Pendidikan juga sangat berperan dalam penerapan metode cooperative learning. Teknolog Pendidikan memiliki kedudukan yang sama dengan profesi lain di dalam bidang pendidikan, hanya saja cakupan dari Teknologi Pendidikan lebih luas yaitu mencakup desain, pengembangan, pemanfaatan, pengelolaan, dan penilaian terhadap sistem, proses, dan sumber belajar untuk kepentingan pembelajaran. Dengan demikian, upaya yang dapat dilakukan oleh Teknolog Pendidikan agar penerapan metode cooperative learning ini berjalan dengan efektif dan efisien yaitu:

1. Menyediakan bahan ajar yang memadai dan sesuai dengan kurikulum yang berlaku sehingga dapat mendorong siswa untuk memperoleh kesempatan belajar yang seluas-luasnya.

2. Menyediakan sarana dan prasarana yang dapat menunjang pembelajaran secara online.

3. Menyediakan media pembelajaran yang memadai sebab media pembelajaran bermanfaat sebagai alat bantu yang fungsinya untuk memperlancar jalannya Kegiatan Belajar Mengajar (KBM) sehingga 
tujuan pembelajaran pun dapat tercapai dengan optimal.

\section{Kelebihan dan Kekurangan dari Penerapan Metode Cooperative Learning dalam Kegiatan Belajar Mengajar (KBM)}

Dalam penerapan metode cooperative learning di masa pandemi Covid-19 ini terdapat beberapa kelebihan dan kekurangan, diantaranya yaitu:

Kelebihan:

1. Meningkatkan kualitas kepribadian yang dimiliki oleh siswa seperti dalam hal kerja sama, berpikir kritis, tolong menolong, menghargai dan menghormati pendapat orang lain, toleransi, dan lain sebagainya.

2. Menumbuhkan semangat berkompetisi secara positif dan konstruktif sebab setiap siswa di dalam kelompok akan berlombalomba untuk menyelesaikan tugas yang telah diberikan oleh guru.

3. Menanamkan rasa persatuan dan solidaritas yang tinggi sebab siswa yang pandai akan dengan senang hati membantu temannya yang kurang memiliki kemampuan dalam memahami materi demi nama baik kelompok mereka.

Kekurangan:

1. Metode ini membutuhkan persiapan yang lumayan rumit apabila dibandingkan dengan metode pembelajaran yang lainnya.

2. Apabila terjadi persaingan yang tidak sehat baik antarsiswa dalam kelompok atau antarkelompok maka hasilnya akan buruk dan jauh dari yang diharapkan.

3. Apabila terdapat siswa yang malas atau siswa yang ingin mendominasi dalam kelompok maka kemungkinan akan menghambat kelompok tersebut dalam mencapai tujuan sehingga usaha kelompok tidak dapat berfungsi sebagaimana semestinya.

\section{PENUTUP}

Berdasarkan hasil penelitian maka dapat disimpulkan bahwa metode cooperative learning efektif diterapkan dalam upaya peningkatan kualitas hasil belajar siswa, baik dilihat dari tingkat partisipasi, interaksi, hasil kuis dan tes, serta hasil tugas kerja kelompok. Selain itu, secara umum siswa juga menggemari metode cooperative learning ini karena dianggap mampu memberikan banyak manfaat. Oleh sebab itu, metode ini dapat dimanfaatkan sebagai solusi alternatif terhadap problematika pembelajaran yang sedang dihadapi oleh siswa di masa pandemi Covid-19. Metode cooperative learning ini menekankan pada tiga aspek utama yang harus dicapai, yaitu antara lain: 1) Peningkatan hasil prestasi akademik siswa yang dapat dilihat dari nilai rata-rata yang telah diperoleh sebelum dan sesudah menerapkan metode cooperative learning. 2) Penerimaan terhadap keberagaman kemampuan dan pemahaman materi dari siswa yang heterogen. 3) Terjadinya peningkatan keterampilan sosial siswa saat mengikuti Kegiatan Belajar Mengajar (KBM). Penjelasan tersebut menunjukkan bahwa penelitian ini dapat menambah pengetahuan dan pemahaman kita mengenai keefektifan dari penerapan metode cooperative learning dalam pembelajaran. Selain itu, metode ini juga dapat memberikan kesempatan bagi siswa untuk berpikir kritis, menjawab pertanyaan, berbagi pendapat dan meningkatkan aktivitas siswa dalam belajar sehingga dapat meningkat kualitas hasil belajarnya.

\section{UCAPAN TERIMA KASIH}

Penulis panjatkan puji syukur kehadirat Tuhan Yang Maha Esa yang senantiasa memberikan rahmat dan hidayah-Nya sehingga penulisan artikel ini dapat terselesaikan tepat pada waktunya. Tak lupa penulis juga mengucapkan terima kasih kepada Bapak Dr. Pujiriyanto, S. Pd., M. Pd. selaku dosen mata kuliah Penulisan Karya Ilmiah yang telah bersedia meluangkan waktu di tengah kesibukannya untuk membimbing dan mengarahkan jalannya penelitian ini. Selain itu, penulis juga mengucapkan terima kasih kepada semua pihak yang telah berpartisipasi untuk mendukung terselesaikannya penelitian dan penulisan artikel ini.

\section{DAFTAR PUSTAKA}

Abdurrahman, M. (2014). Penerapan Strategi Cooperative Learning Dalam Meningkatkan Kemampuan Nahwu Mahasiswa. Jurnal Pendidikan Dan Pembelajaran Universitas Negeri Malang, 21(2), 215-226.

Amaliyah, N., Fatimah, W., \& Abustang, P. B. (2019). Kontribusi Model Pembelajaran Kooperatif Tipe Think Pair Share (TPS) Terhadap Hasil Belajar Ips. Satya Widya, 35(2), 126-139.

Arisanti, D. (2015). Model Pembelajaran Kooperatif pada Pendidikan Agama Islam. Al-Hikmah: Jurnal Agama Dan 
Ilmu Pengetahuan, 12(1), 82-93.

Asdar, A. F. (2016). Pengaruh Pelaksanaan Model Pembelajaran Kooperatif Tipe Think Pair Share Terhadap Hasil Belajar IPS Siswa. Journal Of EST, 2(2), 56-64.

Gumrowi, A. (2016). Strategi Pembelajaran Melalui Pendekatan Kontekstual dengan Cooperative Learning untuk Meningkatkan Hasil Belajar Gelombang Siswa Kelas XII MAN 1 Bandar Lampung. Jurnal Ilmiah Pendidikan Fisika Al-Biruni, 183. https://doi.org/10.24042/jpifalbiruni.v5i2. 118

Lestari, B. (2005). Peningkatan Kualitas Pembelajaran dengan Model Pembelajaran Cooperative Learning Barkah Lestari. 5(2), 145-153.

Muhlis. (2018). Pengaruh Model Pembelajaran Kooperatif Terhadap Motivasi Dan Hasil Belajar Siswa Pada Materi Sistem Koloid SMAN 4 Bantimurung Maros. Jurnal Ilmu Pendidikan, 2(1), 12-24.

Muslich, M. (2007). KTSP Pembelajaran Berbasis Kompetensi dan Kontekstual. Jakarta: Bumi Aksara.

Nur, Mohammad. (2000). Pengajaran Berpusat pada Siswa dan Model Pembelajaran Kontruktivisme dalam Pengajaran.
Surabaya: Universitas Negeri Surabaya. Pitasari, D. E., Maryani, I., \& Purwanto. (2011). Penerapan Metode Cooperative Learning Tipe STAD dengan Media Video Pembelajaran Untuk Meningkatkan Motivasi dan Hasil Belajar Siswa Kelas III SD Negeri Pucung. 270-279.

Pujiono, R. (2017). Penerapan Model Pembelajaran Kooperatif Tipe Student Team Achievement Divisions (Stad) Untuk Meningkatkan Motivasi Dan Hasil Belajar Ipa Siswa Kelas VB Sdn 047 Tarakan. Journal of Education Research and Evaluation, 1(4), 198-203.

Sanjaya, Wina. (2012). Strategi Pembelajaran Berorientasi Standar Proses Pendidikan. Jakarta: Kencana Media Group.

Slavin, R. E. (2011). Cooperative Learning, Teori, Riset dan Praktik. Bandung: Nusa Media.

Susanto, A. (2013). Teori Belajar dan Pembelajaran di Sekolah Dasar. Jakarta: Kencana Prenadamedia Group.

Sujana, I. W. C. (2019). Fungsi Dan Tujuan Pendidikan Indonesia. Adi Widya: Jurnal Pendidikan Dasar, 4(1), 29. https://doi.org/10.25078/aw.v4i1.927 